\title{
応答曲面を用いた数値解析援用 確率論的津波ハザード評価
}

\author{
小谷 拓磨 ${ }^{1} \cdot$ 高瀬 慎介 ${ }^{2} \cdot$ 森口 周二 $^{3}$ ・寺田 賢二郎 ${ }^{4} \cdot$

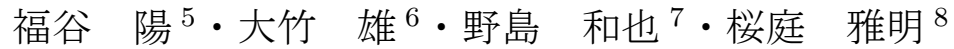 \\ 1学生員 東北大学大学院 工学研究科（９ 980-0845 宮城県仙台市青葉区荒巻字青葉 468-1） \\ E-mail: kotani99@dc.tohoku.ac.jp \\ 2 正会員 東北大学助教 工学部（９９80-0845 宮城県仙台市青葉区荒巻字青葉 468-1） \\ E-mail: takase@irides.tohoku.ac.jp \\ 3 正会員 東北大学准教授 災害科学国際研究所（９ 980-0845 宮城県仙台市青葉区荒巻字青葉 468-1） \\ E-mail: s_mori@irides.tohoku.ac.jp \\ 4 正会員 東北大学教授 災害科学国際研究所（T 980-0845 宮城県仙台市青葉区荒巻字青葉 468-1） \\ E-mail: tei@irides.tohoku.ac.jp \\ 5 正会員＼cjkstart東京海上日動リスクコンサルティング株式会社 企業財産本部（† 100-0005 東京都千代田区丸の内 1-2-1） \\ E-mail: you.fukutani@tokiorisk.co.jp \\ 6 正会員 新潟大学准教授 工学部（９ 950-2181 新潟県新潟市西区五十嵐 2 の町 8050) \\ E-mail:y_ohtake@eng.niigata-u.ac.jp \\ 7 正会員 日本工営株式会社 中央研究所（广 300-1259 茨城県つくば市稲荷原 2034） \\ E-mail: a7385@n-koei.co.jp \\ 8 正会員 日本工営株式会社 中央研究所（广 300-1259 茨城県つくば市稲荷原 2034） \\ E-mail: sakuraba-ms@n-koei.jp
}

\begin{abstract}
本研究では, 津波解析から得られる情報を効率的に利用して確率論的津波八ザード評価を達成する手法を提 案する. この手法は, 津波解析の結果に基づき評価する対象事象の応答曲面を作成する特徵を有する. また, 津 波解析に関する不確実性を定量化する。これにより，高度な津波解析の結果に基づくモンテカルロシミュレー ションの実施を可能としている. 適用例では, 一部の断層パラメータおよび津波解析手法のモデル化誤差の不 確実性を定量化し, 東北地方太平洋沖地震時の仙台・石巻 - 釜石における最大津波高さの確率密度分布を評価 した，その結果，提案する手法が確率論的津波ハザード評価に対して有効であることを確認した.
\end{abstract}

Key Words: probabilistic tsunami hazard analysis, response surface, Monte Carlo method, uncertainty analysis

\section{1.はじめに}

兵庫県南部地震や東北地方太平洋沖地震の地震動に よる被害，および近年多発する集中豪雨による洪水や 土砂災害の被害は，我が国の防災技術・枠組みに多くの 課題を突き付けている。 その中でも工学的に特に重要 な課題として，極めて大きな外力の評価が挙げられる. この問題に対応する手段の 1 つとして, 確率論に基づ くハザードやリスク評価に関する手法や枠組みが，精 力的に議論されている. 確率論的ハザード評価につい ては，地震の分野において古くから研究が行われてお り, Cornell ${ }^{1)}$ の研究などがその先駆けとして知られて いる。また，我が国においては，原子力発電所を評価 対象とした亀田 ${ }^{2)}$ の研究などが先駆的である.ささらに, 近年では, 地震動だけでなく, 地震に伴って発生する 津波についても確率論的に評価しようとする研究が進 んでいる. 東北地方太平洋沖地震以降にこの動きが加 速したが，研究自体はそれよりも前から行われている. 土木学会原子力土木委員会津波評価部会は, 確定論的 評価 ${ }^{3)}$ の枠組みを拡張し, 2007 年に確率論に基づく津
波水位の評価方法 ${ }^{4)}$ を示している。また，同委員会は， 東北地方太平洋沖地震による被害により津波の確率論 的評価の社会的要請が強くなったことを受け，「確率論 的津波ハザード解析の方法」5) を公開している.この中 では，考えるべき不確実性について，実現象が持つ不 確実性である偶然的ばらつきと, 知識やデータの不足 およびモデル化の精度に起因する認識論的不確実性の 2 種類に分け, 後者の評価にはロジックッリー手法を用 いている。この資料の中には, 東北地方太平洋沖地震 の知見は含まれていないが，その後に原子力安全基盤 機構がまとめた手引き6)では, 東北地方太平洋沖地震 の知見を含めた評価手法が提案され，実際のサイト の適用を通じて具体的な技術事項が例示されている.

先述のように，津波を対象とした確率論的評価につ いては, 具体的な枠組みが構築され, 適用事例までが 示されている. しかしながら, 現状の確率論的評価の 枠組みの中では,「予測」の役割を担う数值解析が効果 的に用いられているとは言い難い。例えば,「確率論的 津波ハザード解析の方法」5) の中では，ある特定の地震 
に対する特定地点の最大津波高さの確率密度関数を求 めることが必要となるが, 最大津波高さの確率密度分 布を表現する分布関数は対数正規分布として予め設定 されており, 数值解析結果は分布関数の中央値を評価 する目的ために用いられる.また，そのばらつき（標準 偏差）は相田 ${ }^{7)}$ が提案した津波痕跡高と計算值の空間 的適合度を表寸指標によって表現される. 従って, 数値 解析結果から直接的に確率密度分布が得られるわけで はない。数值解析の役割は, 最大津波高さの確率密度 分布の一部の特性を決めるために限定して用いられる ため，その構造はシンプルで扱いやすいものであるが， 数值解析の結果は部分的にしか使われていない. 一方 で，近年の津波数值解析は，計算機能力や並列計算技 術の急速な発展に伴い, 目覚ましい速度で高速化が達 成されており, リアルタイムの津波数值解析に関する 報告 ${ }^{8)}$ もある. そのため, 現象の確率密度分布そのも のを数值解析によって表現できる可能性がある。この ような観点から, 本研究では, 津波八ザードの確率論 的評価の中で, 現代の高度化した数值解析を有効に活 用するための手法を提案する.

数值解析と確率論の融合については, 特に有限要素 法（FEM: Finite Element Method）をベースとした研究 成果が既に報告されている。例えば，一次近似二次モ一 メント（FOSM: First-Order Second-Moment Method）法 の考え方を有限要素法に展開可能であることを示した Cornel1 ${ }^{9)}$ や $\mathrm{Cambou}^{10)}$ の研究があり, 我が国では中桐 $5^{11)}$, 桜井・土居 ${ }^{12)}$, 鈴木・石井 ${ }^{13)}$ の研究が先駆的な ものとして挙げられる。これらの研究成果は, 学術的 に貴重な研究成果である一方で, 数值解析と確率理論 が直接的に関係づけられ，実務利用レベルでは計算コ ストが大きな問題となる，そこで，本研究では，Zhang $ら^{14)}$ や本城ら ${ }^{15)}$, Honjo ${ }^{16}$ の 研究に見られる応答曲 面を用いる枠組みを基礎として, 数值解析を効率的に 用いた津波の確率論的評価手法を提案するものとする. 特に, 本城らが提案する枠組みは, 液状化地盤上の水 路の八ザード評価 ${ }^{17)}$ や落石の危険度評価 ${ }^{18)}$ など，実 問題に適用した事例の中でその有用性が確認されてい ることから, 本研究でもその枠組みを基礎とする. 東 北地方太平洋沖地震の津波を対象として評価の具体的 な手順を示し, 数值解析を有効に活用した確率論的評 価の優位性や課題について整理する.

\section{2. 信頼性設計の枠組み}

\section{（1）基本となる信頼性解析のスキーム}

本城らは，地盤構造物の実務的なレベル III の信頼性 設計のスキームとして, 図-1に示寸枠組みを提案して いる ${ }^{16)}$ 。この枠組みは, 高度な現代の解析技術や設計 ツールに基づいた信頼性解析の達成を可能とするもの

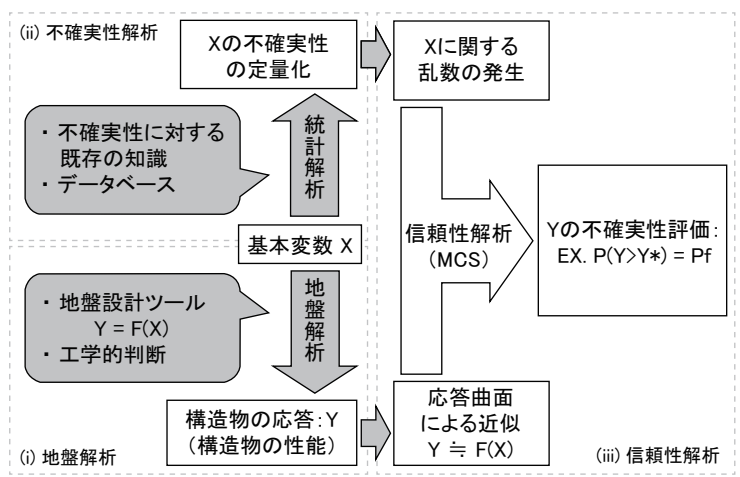

図-1 数值解析を用いた地盤構造物の信頼性設計の枠組み 16$)$

である. 通常, 高度な数值解析や設計ツールを用いて 対象事象の評価を行う場合，その計算コストの制約に より, 実務レベルでは十分な試行回数の確保が難しく, 十分な精度での信頼性解析を実施することが難しい. 本 城らの提案する枠組みでは，この問題を解決するため に, 高度な数值解析や設計ツールの結果を応答曲面と 呼ばれる数式に集約する. 以下では, この枠組みの具体 的な手順について説明する. まず, 評価の対象となる対 象事象 $Y$ を決定寸る. また, 対象事象 $Y$ に対して支配 的と考えられる基本変数 $X$ をリストアップする. その 後の作業は, (i) 数值解析（図-1 では地盤解析と表現）, (ii) 不確実性解析, (iii) 信頼性解析の 3 種類のプロセス に分けられる. まず, 数值解析 (数值解析や設計ツール によるパラメトリックスタディ）により, 基本変数 $X$

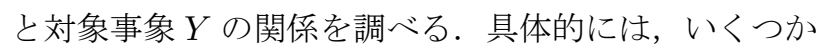
の基本変数の組み合わせに対して対象事象の応答を確 認する. この結果は, 後述する応答曲面を構築するた めの材料として用いられる. この工程の中では, 解析 者が計算結果を通じて, 各基本変数が対象事象に与え る影響を確認することになるが，解析者の工学的知見 や経験に基づいて結果を分析することで, 対象事象 $Y$ に関する物理やメカニズムに関する感覚を養うことが できる，次に，不確実性解析のプロセスに移る。この 工程では, 基本変数 $X$ のばらつきを定量化する. 例え ば，基本変数が量的変数である場合には，その平均值， 分布関数，標準偏差などの情報を整備すればよい，ま た，質的変数である場合にはその出現確率などを整備 寸ればよい。この工程では, 基本変数 $X$ に対する経験 的な知見や蓄積されているデータベースの情報, およ び対象とする現場の状況などから, 基本変数のばらつ きを定量化する．十分にデータが揃っている場合には そのデータに基づき定量化すればよいが，現実には完 全に十分なデータが整備されていることは少なく, 工 学的な判断に頼らざるを得ない場合が多い.

最後の信頼性解析では，まず，(i) の数值解析で得られ た結果を用いて, 基本変数 $X$ に対寸る対象事象 $Y$ の応 答曲面を仮定寸る. 具体的には, 対象事象 $Y$ の量や確率 
などを出力する数学的な関数（応答曲面）を構築する. この関数は, 基本変数 $X$ が含まれ，(i) の数值解析の結 果と整合するように係数等が決定される.さらに，ここ で得られた応答曲面と, (ii) の不確実性解析で定量化さ れた基本変数のばらつきの情報に基づいて，モンテカ ルロシミュレーション (MCS: Monte Carlo Simulation) を実施する．すなわち基本変数のばらつきを考慮して 数多くの基本変数の組み合わせを用意し，それを応答 曲面の関数に代入して対象事象 $Y$ の值を計算する。こ れによって, 対象事象の確率密度分布を得ることがで きる. 応答曲面は, (i) の数值解析の結果に基づいて得 られたものであるため，それを通じて対象事象の確率 密度分布を得るということは, 間接的に高度な数值解 析や設計ツールに基づいて対象事象の確率密度分布を 得ていることになる.

\section{（2）津波解析による危険度評価への適用}

上述の信頼性設計のスキームでは, 地盤解析のプロ セスとその他のプロセスが独立しているため, 解く心゙ き問題に対して解析ツールを変更寸ることが可能であ る. 本研究の内容では, 津波解析が地盤解析の部分に該 当する。ここでは，スキームを本研究に適用した場合 の具体的な流れについて説明する. 図-2に示すように, まず信頼性解析を行う対象事象を決定する．対象事象 は，例えば，最大津波高さなどの物理的な量が考えら れる、また，ある地点領域に浸水が到達するか否かを という選択的なものであってもよい. 定量的か選択的 かという違いは, 応答曲面を構成する数式の種類の違 いとなって現れる.

次に，基本変数について検討する. 実質的には，こ の検討は後に続く津波解析の条件設定と強く関係する. なぜなら，津波解析における解析条件や解析パラメー 夕の多くは, 解析結果に大きな影響を与えるものであ り, これらが応答曲面の基本変数となる可能性が高い ためである，そのため，解析を実施する段階で，基本変 数の検討を並行して実施するイメージである.ただし， この段階では, 基本変数を必ずしも絞り込む必要はな い. シミュレーション実施者の工学的判断に基づいて, 現象に対して支配的と考えられる解析条件や解析パラ メータを変化させて複数ケースのシミュレーションを 実施すればよい。シミュレーションは対象事象を観察 するための数值解析として位置づけられ，実施者はそ の数值解析を通して各基本変数が対象事象に与える影 響を学習することになる. 従って, シミュレーション を実施する前に変化させる解析条件や解析パラメータ の種類とその範囲を確定的に設定するよりも，シミュ レーションを実施していく中で，出力される結果を観 察しながらそれらを決定していく方が効果的かつ現実

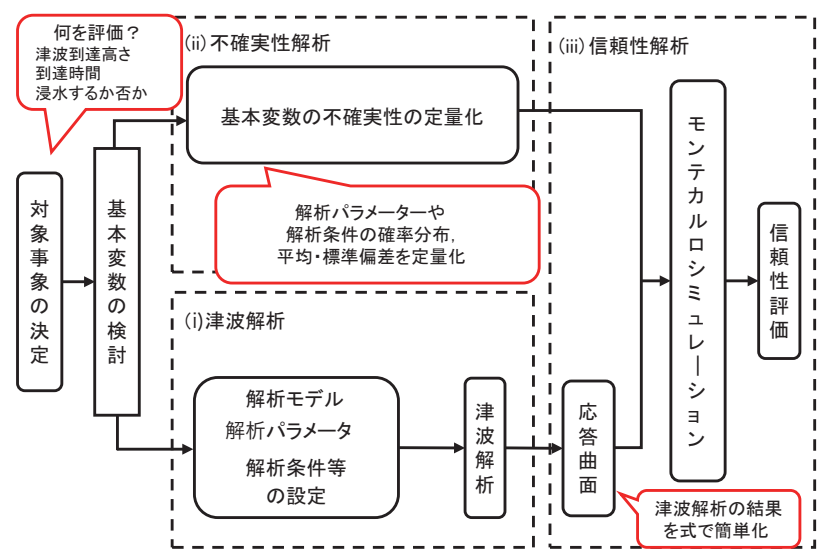

図-2 提案する確率論的津波ハザード評価手法

的である.またこのシミュレーションのプロセスにお いては, 膨大な量の解析ケースを実施する必要はなく, 各基本変数が対象事象に与える傾向を確認寸ることが できる程度の解析結果を揃えればよい，なお，このシ ミュレーションのプロセスでは, 調査結果などから解 析パラメータなどを推定する際の「変換誤差」が含ま れ, 加えて, 津波解析モデルの「モデル化誤差」も不確 実性として存在するが，これらの不確実性については， その定量化のためには別途十分な検証データが必要と なる。また, 津波解析と並行して, 不確実性解析を実 施する．これは後述する MCS の入力パラメータを作成 するための基礎データとなる基本変数の分布情報（平 均值, 分散, 分布形状）を決定するプロセスである.

最後に, 津波解析と不確実性解析の結果に基づいて 信頼性解析を実施する．まず，津波解析の結果に基づい て応答曲面を構築する。 これは, 基本変数を含む対象 事象の数学的関数の構築を意味する. 津波解析の結果 はこの関数式に集約される. 津波解析では海底地形や 遡上地形の形状を直接的に表現するため，これらの効 果も応答曲面には含まれており, 同じ対象事象でも解 析対象地域によって応答曲面は異なるものとなる。応 答曲面を構築した後は，その応答曲面と不確実性解析 の中で定量化した基本変数の情報を用いて MCS を実施 する，応答曲面を用いることで，膨大な計算ケースの 実施が可能となり，断層モデルを逐一変化させて津波 解析から対象事象の確率密度分布を得るよりも密な結 果を低計算コストで得ることが出来る。また，得られ た確率密度分布から対象事象に関する危険度を確率論 的に論じることが可能となる。

\section{3. 津波解析}

\section{(1) 対象事象と基本変数の検討}

本研究では, 津波解析における海岸近傍の「最大津 波高さ」を対象事象 $Y$ としてハザード評価を実施する. これは, これまでの我が国の経験と知見・様々な研究 
から最大津波高さが海岸構造物への被害に密接に関係 していると推定されるためである.

次に基本変数を検討する.まずは関与するパラメー タを列挙する．津波発生から遡上までの現象の支配因 子は様々であり，またそれらは複合的な作用をもたら して津波の規模を変化させる．例えば津波解析におけ る支配因子として，地震発生の過程では地震活動の位 置やマグニチュードの大きさなどが挙げられ，津波伝 播の過程では津波の初期波形を支配する断層モデルや 海底地形データ, 潮位, 浅水長波式に代表される伝播の 支配方程式などが挙げられ，津波遡上の過程では，陸 上地形データ，建物や防潮堤・防潮林などを表す遡上 抵抗モデル（粗度データや越流モデル），および遡上 時の波の支配方程式などが挙げられる．津波のハザー ド評価を行う際，これらすべての要因が不確実性を持 つことになる．最終的にはすべての不確実性を基本変 数 $X$ として与えることが最も望ましいことであるが， 信頼性解析を実務で扱う場合には，ある程度その現象 を支配しているパラメータにあたりをつけると効率が 良い. 今村・首藤 ${ }^{19)}$ は, 津波解析においては主として 断層パラメータが最大津波高さや波の指向性に大きく 関係していることを明らかにしている．また，原子力 土木委員会津波評価部会 ${ }^{3)}$ は，津波解析に用いる断層 モデルの各パラメータを合理的範囲で変化させてパラ メトリックスタディを行うことで，各パラメータが最 大津波高さに及ぼす影響の程度をまとめている。本研 究ではこれに基づき，図-3に示す Satake ら 20) による 東北地方太平洋沖地震の断層面上の時空間的なすべり 分布を推定した，55 の小断層で構成される断層モデル （Fujii-Satake モデル Ver.8.0）を用い，基本変数 $X$ とし て, 図-4に示す小断層における各断層パラメータの中 でも断層の食い違い量の特性に関係が深いと考えられ る「すべり量 (Slip)」及び「すべり角 (Rake)」を設定し た。なお，図-3における白星は震源，菱形は GPS 波浪 計，四角は海底圧力計である。

\section{(2) 解析条件}

本解析の中で考えるすべり量とす心゙り角のばらつき は，表-1に示す各小断層ごとに割り振られた断層パラ メータを基準に決定する．表-1では簡単のために，本 来断層運動開始から 30 秒間隔毎に計 5 分間の経時変化 を与えている各パラメータの総計值を示しており，本解 析もその効果を考慮している．時刻歴変化を考慮した詳 細なパラメータに関しては，Satakeら 20) を参照された い. 本研究で行う解析ケースとそのケース名は表-2に 示すとおりであり，各小断層のすべり量に対して 0.7 , 0.85，1.0，1.2，1.4 を乗じた 5 パターン，及びすべり 角に対して -10 度， -5 度， \pm 0 度， 5 度， 10 度を加減

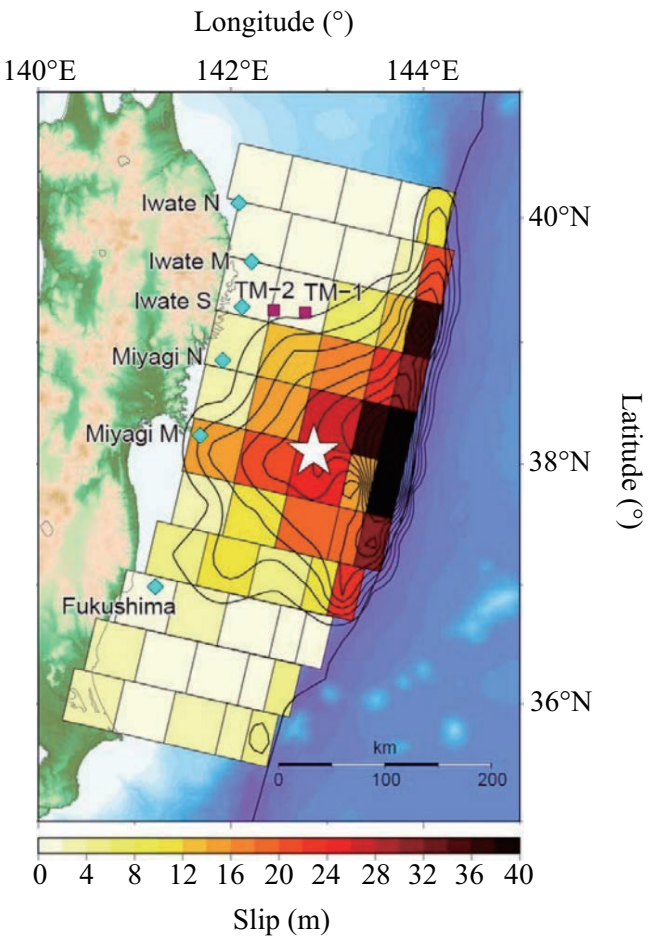

図-3 55 個の小断層からなる Fujii-Satake ver.8.0 モデル ${ }^{20)}$

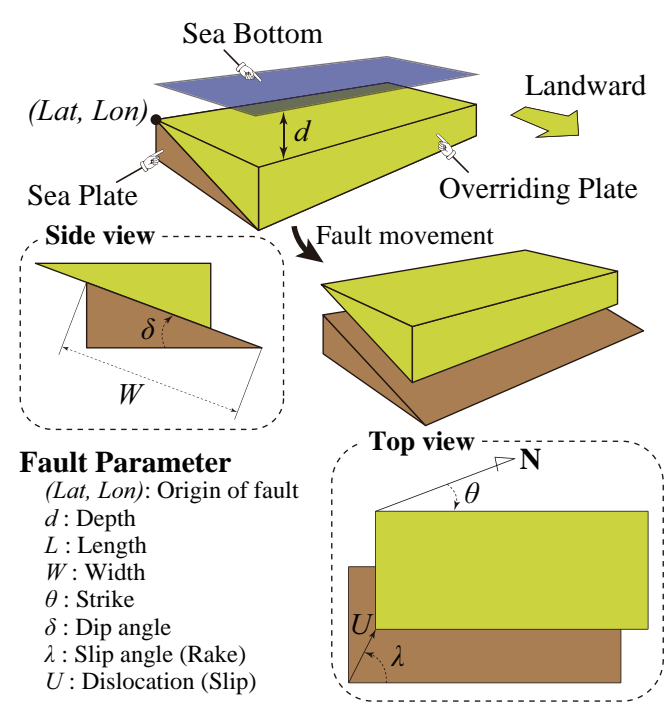

図-4 小断層におけるパラメータの概要

させた 5 パターンを考慮した，計 25 ケースを解析する. このパラメータ幅は，後述するモンテカルロシミュレー ションにおいてパラメータが変動する幅を概ねカバー するように設定している．すなわちケース「A3B3」に おけるすべり量とすべり角のばらつきは零である。 そ の他の解析条件を表-3に示す．津波の初期波形につい ては, Fujii-Satake モデル Ver.8.0に対して, Okadaの方 法21) を用いて断層モデルから海底地凯変動量の鉛直成 分を計算し, 初期水位変動量として与える方法を用い ている.また，津波伝播の数值計算においては，式 (1) に示す連続の式と, 式 (2) および式 (3) に示す非線形長 波方程式を用いている。 
表-1 Fujii-Satake モデル Ver.8.0 の各小断層のパラメータ

\begin{tabular}{|c|c|c|c|c|c|c|c|c|}
\hline $\begin{array}{l}L \\
{[\mathrm{~m}]}\end{array}$ & $\begin{array}{l}W \\
{[\mathrm{~m}]}\end{array}$ & $\begin{array}{l}D \\
{[\mathrm{~km}]}\end{array}$ & $\begin{array}{l}\theta \\
{\left[{ }^{\circ}\right]}\end{array}$ & $\begin{array}{l}\delta \\
{\left[{ }^{\circ}\right]}\end{array}$ & $\begin{array}{l}\lambda \\
{\left[{ }^{\circ}\right]}\end{array}$ & $\begin{array}{l}U \\
{[\mathrm{~m}]}\end{array}$ & $\begin{array}{l}\text { Lat. } \\
\text { [decimal }\end{array}$ & $\begin{array}{l}\text { Lon. } \\
\text { ystem] }\end{array}$ \\
\hline 50 & 25 & 0 & 193 & 8 & 81 & 10.699 & 40.198 & 144.350 \\
\hline 50 & 25 & 0 & 193 & 8 & 81 & 20.492 & 39.738 & 144.331 \\
\hline 50 & 25 & 0 & 193 & 8 & 81 & 36.079 & 39.300 & 144.200 \\
\hline 50 & 25 & 0 & 193 & 8 & 81 & 30.647 & 38.862 & 144.069 \\
\hline 50 & 25 & 0 & 193 & 8 & 81 & 51.893 & 38.424 & 143.939 \\
\hline 50 & 25 & 0 & 193 & 8 & 81 & 69.141 & 37.986 & 143.810 \\
\hline 50 & 25 & 0 & 193 & 8 & 81 & 31.715 & 37.547 & 143.682 \\
\hline 50 & 25 & 0 & 193 & 8 & 81 & 22.450 & 37.135 & 143.400 \\
\hline 50 & 25 & 0 & 193 & 8 & 81 & 0.759 & 36.730 & 143.070 \\
\hline 50 & 25 & 0 & 193 & 8 & 81 & 4.333 & 36.325 & 142.740 \\
\hline 50 & 25 & 0 & 193 & 8 & 81 & 5.905 & 35.905 & 142.504 \\
\hline 50 & 25 & 3.5 & 193 & 8 & 81 & 0.840 & 40.248 & 144.066 \\
\hline 50 & 25 & 3.5 & 193 & 8 & 81 & 2.982 & 39.788 & 144.049 \\
\hline 50 & 25 & 3.5 & 193 & 8 & 81 & 13.705 & 39.350 & 143.920 \\
\hline 50 & 25 & 3.5 & 193 & 8 & 81 & 22.425 & 38.912 & 143.790 \\
\hline 50 & 25 & 3.5 & 193 & 8 & 81 & 37.381 & 38.474 & 143.662 \\
\hline 50 & 25 & 3.5 & 193 & 8 & 81 & 14.932 & 38.036 & 143.535 \\
\hline 50 & 25 & 3.5 & 193 & 8 & 81 & 19.127 & 37.597 & 143.408 \\
\hline 50 & 25 & 3.5 & 193 & 8 & 81 & 10.108 & 37.185 & 143.128 \\
\hline 50 & 25 & 3.5 & 193 & 8 & 81 & 0.000 & 36.780 & 142.799 \\
\hline 50 & 25 & 3.5 & 193 & 8 & 81 & 1.827 & 36.375 & 142.471 \\
\hline 50 & 25 & 3.5 & 193 & 8 & 81 & 2.531 & 35.955 & 142.236 \\
\hline 50 & 50 & 7 & 193 & 10 & 81 & 1.342 & 40.298 & 143.782 \\
\hline 50 & 50 & 7 & 193 & 10 & 81 & 0.225 & 39.838 & 143.767 \\
\hline 50 & 50 & 7 & 193 & 10 & 81 & 6.653 & 39.400 & 143.639 \\
\hline 50 & 50 & 7 & 193 & 10 & 81 & 16.896 & 38.962 & 143.512 \\
\hline 50 & 50 & 7 & 193 & 10 & 81 & 26.552 & 38.524 & 143.385 \\
\hline 50 & 50 & 7 & 193 & 10 & 81 & 24.674 & 38.086 & 143.260 \\
\hline 50 & 50 & 7 & 193 & 10 & 81 & 18.059 & 37.647 & 143.135 \\
\hline 50 & 50 & 7 & 193 & 10 & 81 & 4.829 & 37.235 & 142.856 \\
\hline 50 & 50 & 7 & 193 & 10 & 81 & 0.000 & 36.830 & 142.529 \\
\hline 50 & 50 & 7 & 193 & 10 & 81 & 0.606 & 36.425 & 142.201 \\
\hline 50 & 50 & 7 & 193 & 10 & 81 & 2.349 & 36.005 & 141.968 \\
\hline 50 & 50 & 15.6 & 193 & 12 & 81 & 0.652 & 40.398 & 143.216 \\
\hline 50 & 50 & 15.6 & 193 & 12 & 81 & 1.059 & 39.938 & 143.205 \\
\hline 50 & 50 & 15.6 & 193 & 12 & 81 & 0.000 & 39.500 & 143.081 \\
\hline 50 & 50 & 15.6 & 193 & 12 & 81 & 13.144 & 39.062 & 142.957 \\
\hline 50 & 50 & 15.6 & 193 & 12 & 81 & 15.548 & 38.624 & 142.834 \\
\hline 50 & 50 & 15.6 & 193 & 12 & 81 & 21.579 & 38.186 & 142.711 \\
\hline 50 & 50 & 15.6 & 193 & 12 & 81 & 10.872 & 37.747 & 142.590 \\
\hline 50 & 50 & 15.6 & 193 & 12 & 81 & 10.525 & 37.335 & 142.314 \\
\hline 50 & 50 & 15.6 & 193 & 12 & 81 & 2.122 & 36.930 & 141.990 \\
\hline 50 & 50 & 15.6 & 193 & 12 & 81 & 0.080 & 36.525 & 141.665 \\
\hline 50 & 50 & 15.6 & 193 & 12 & 81 & 1.966 & 36.105 & 141.435 \\
\hline 50 & 50 & 26 & 193 & 16 & 81 & 0.816 & 40.497 & 142.654 \\
\hline 50 & 50 & 26 & 193 & 16 & 81 & 0.000 & 40.037 & 142.646 \\
\hline 50 & 50 & 26 & 193 & 16 & 81 & 0.000 & 39.599 & 142.526 \\
\hline 50 & 50 & 26 & 193 & 16 & 81 & 2.813 & 39.161 & 142.405 \\
\hline 50 & 50 & 26 & 193 & 16 & 81 & 2.412 & 38.723 & 142.285 \\
\hline 50 & 50 & 26 & 193 & 16 & 81 & 14.263 & 38.285 & 142.166 \\
\hline 50 & 50 & 26 & 193 & 16 & 81 & 2.674 & 37.846 & 142.048 \\
\hline 50 & 50 & 26 & 193 & 16 & 81 & 4.475 & 37.434 & 141.775 \\
\hline 50 & 50 & 26 & 193 & 16 & 81 & 0.000 & 37.029 & 141.453 \\
\hline 50 & 50 & 26 & 193 & 16 & 81 & 2.751 & 36.624 & 141.132 \\
\hline 50 & 50 & 26 & 193 & 16 & 81 & 2.553 & 36.204 & 140.905 \\
\hline
\end{tabular}

$$
\frac{\partial \eta}{\partial t}+\frac{\partial M}{\partial x}+\frac{\partial N}{\partial y}=0
$$

$$
\begin{aligned}
\frac{\partial M}{\partial t}+\frac{\partial}{\partial x} & {\left[\frac{M^{2}}{D}\right]+\frac{\partial}{\partial y}\left[\frac{M N}{D}\right] } \\
& +g D \frac{\partial \eta}{\partial x}+\frac{g n^{2}}{D^{7} / 3} M \sqrt{M^{2}+N^{2}}=0
\end{aligned}
$$

$$
\begin{aligned}
\frac{\partial N}{\partial t}+\frac{\partial}{\partial x} & {\left[\frac{M N}{D}\right]+\frac{\partial}{\partial y}\left[\frac{N^{2}}{D}\right] } \\
& +g D \frac{\partial \eta}{\partial y}+\frac{g n^{2}}{D^{7} / 3} N \sqrt{M^{2}+N^{2}}=0
\end{aligned}
$$

\begin{tabular}{|c|c|c|c|c|c|c|}
\hline & \multicolumn{5}{|c|}{ 断層すべり角 (Rake)の増分 } \\
\hline & & -10 度 & -5 度 & 0 度 & 5 度 & 10 度 \\
\hline \multirow{5}{*}{ 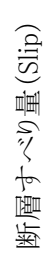 } & $70 \%$ & A1B1 & A1B2 & A1B3 & A1B4 & A1B5 \\
\hline & $85 \%$ & $\mathrm{~A} 2 \mathrm{~B} 1$ & A2B2 & A2B3 & A2B4 & A2B5 \\
\hline & $100 \%$ & A3B1 & A3B2 & A3B3 & A3B4 & A3B5 \\
\hline & $120 \%$ & A4B1 & A4B2 & A4B3 & A4B4 & A4B5 \\
\hline & $140 \%$ & A5B1 & A5B2 & A5B3 & A5B4 & A5B5 \\
\hline
\end{tabular}

表-2 解析ケース

表-3 解析条件の一覧

\begin{tabular}{c|c}
\hline 項目 & 内容 \\
\hline 計算格子間隔 & 領域 $1: 2430[\mathrm{~m}]$ \\
※中央防災会議 & 領域 $2: 810[\mathrm{~m}]$ \\
2013 の設定に & 領域 $3: 270[\mathrm{~m}]$ \\
淮ずる & 領域 $4: 90[\mathrm{~m}]$ \\
\hline 境界条件 & 沖側境界 : 透過境界 \\
& 陸側境界 : 完全反射境界 \\
\hline 計算潮位 & 地震発生時の潮位 $($ T.P. -0.57[m] $)$ \\
\hline 基礎方程式 & 非線形長波方程式 \\
\hline 計算手法 & Leap-Frog 法及びStaggered 格子 \\
\hline 対象地震津波 & 東北地方太平洋沖地震 \\
\hline 断層モデル & Fujii-Satake モデル Ver8.0 \\
\hline & Okada(1992)の方法により \\
津波初期波源 & 断層モデルから地款変動量 \\
& 及び水位変動量を計算 \\
\hline 計算再現時間 & 地震発生から 3 時間 \\
\hline
\end{tabular}

ここに, $\eta$ は水位, $D$ は全水深, $g$ は重力加速度, $n$ は Manning の粗度係数, $M$ と $N$ は $x$ 方向および $y$ 方向の 流量フラックスである。また, 計算スキームには LeapFrog 法及び Staggered 格子に基づく平面 2 次元浅水流モ デル22）を採用した。本解析 25 ケースでは, 図-5, 6 に 示す宮城県の仙台・石巻と岩手県の釜石の計 3 点を観測 点として設けた。これに応じて計算格子は, 図-7, 8に 示すような, 2013 年中央防災会議の報告書 ${ }^{23)}$ に準じた 2430[m]，810[m]，270[m]，90[m] 間隔のメッシュを作 成し, 津波波源から対象に向かって細分化するようにネ スティングした。陸域・海域の標高をメッシュに補間す る際には，2430[m]，810[m]，270[m] メッシュには陸・ 海底地形をデータセットとして含む ETOPO124) を補間 した.また，90[m]メッシュには, 詳細な陸域データと して国土地理院が提供する $10 \mathrm{mDEM}$ データ ${ }^{25)}$, 及び 詳細な近海の海底地形データとして M7000 シリーズの 等水深線データ 26) を補間し，これらで対応できない範 囲はETOPO1 で補間した。なお，陸海境界は，海域で の実現象の再現性が比較的に透過境界よりも高い完全 反射境界としている. 


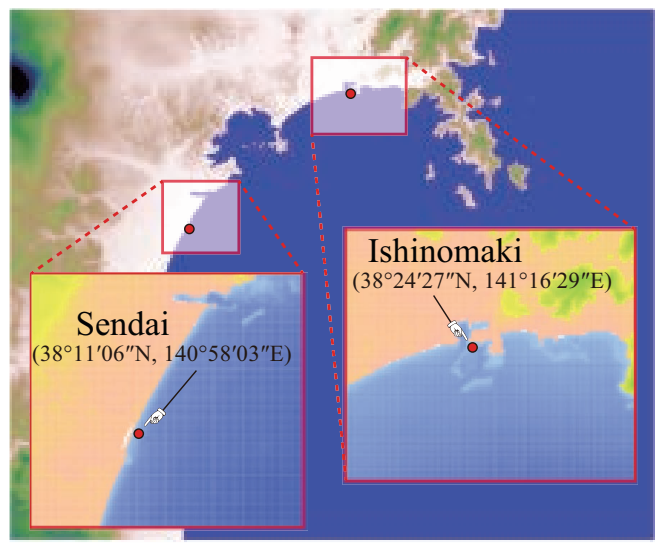

図-5 仙台・石巻における最大津波高さの観測点

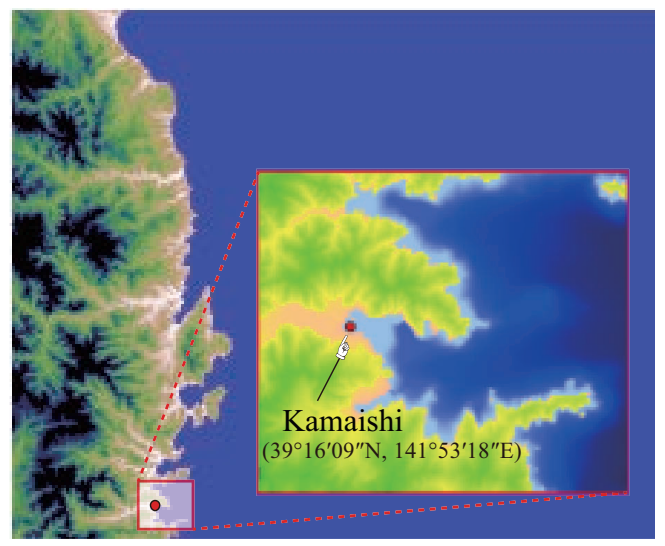

図-6 釜石における最大津波高さの観測点

\section{(3) 解析結果}

\section{a) 津波解析モデルの妥当性の検証}

本研究に用いる津波解析モデルの妥当性を確認する ため, 東北地方太平洋沖地震時の津波の実測值と FujiiSatake モデルの断層パラメータの基準值を用いた津波 解析の計算值における水位変動量の時刻歴を比較した. 実測值としては，国土交通省港湾局の提供する NOWPHAS (Nationwide Ocean Wave infomation network for Ports and HArbourS）の GPS 波浪計観測データ 27) を用 いた。観測位置は，図-9に示寸岩手県北部沖（No.1）, 岩手県中部沖 (No.2), 岩手県南部沖 (No.3), 宮城県 北部沖（No.4）, 宮城県中部沖（No.5）の 5 点とした. 検証結果を図-10に示す.いずれの観測点においても解 析結果が実測值を概衩再現出来ており，本稿に用いた 津波解析ツールの妥当性を確認できた。なお，ここで の更なる誤差抑制は数值解析技術の課題となるが，本 研究の手法では後にモデル化誤差としてこれを定量化 している，その詳細については後述するものとする。

\section{b) 各解析ケースの結果}

本解析 25 ケースにおける，津波発生から 3 時間まで の間での各地域の最大津波高さの分布図を図-11, 12 に, 3 地点の最大津波高さをまとめたものを表-4に示す。こ

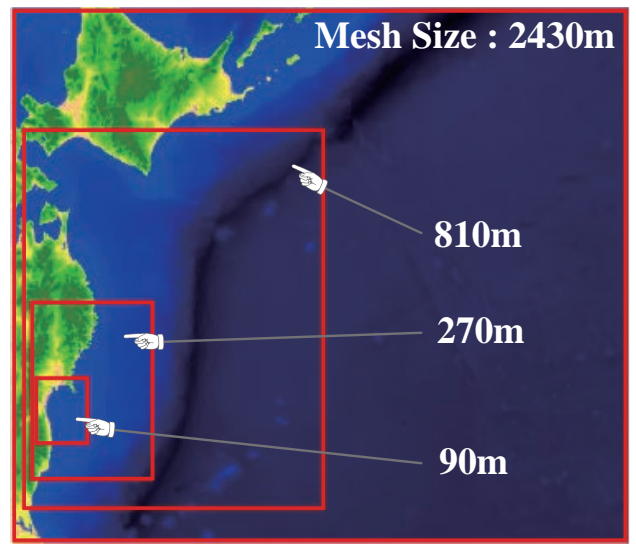

図-7 宮城県沖のメッシュ領域

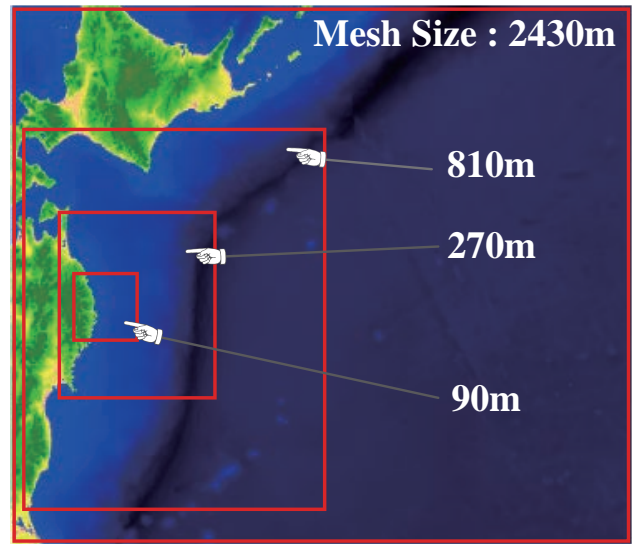

図-8 岩手県沖のメッシュ領域

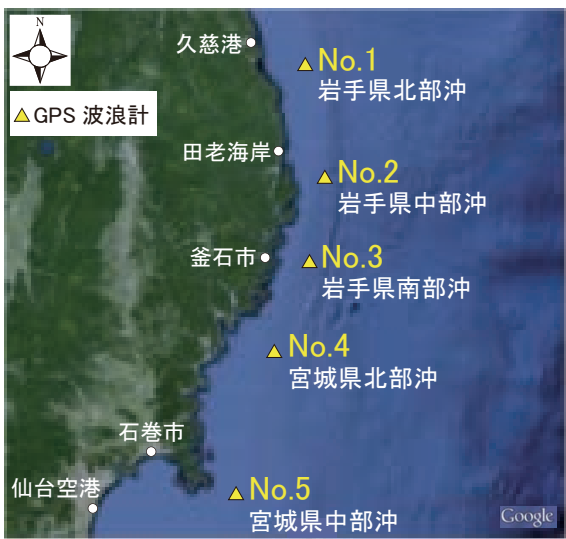

図-9 水位変動量の観測点 No.1〜No.5（Google Earth に加筆）

れらの結果は，どの地点でも概ねすべり量が支配的で あることを示している。

\section{4. 不確実性解析（基本変数のばらつきの定 量化)}

ここでは，不確実性解析について説明する．先述の 用に，不確実性解析では，基本変数のばらつきを定量 化する作業であり，この定量化された情報は，その後 


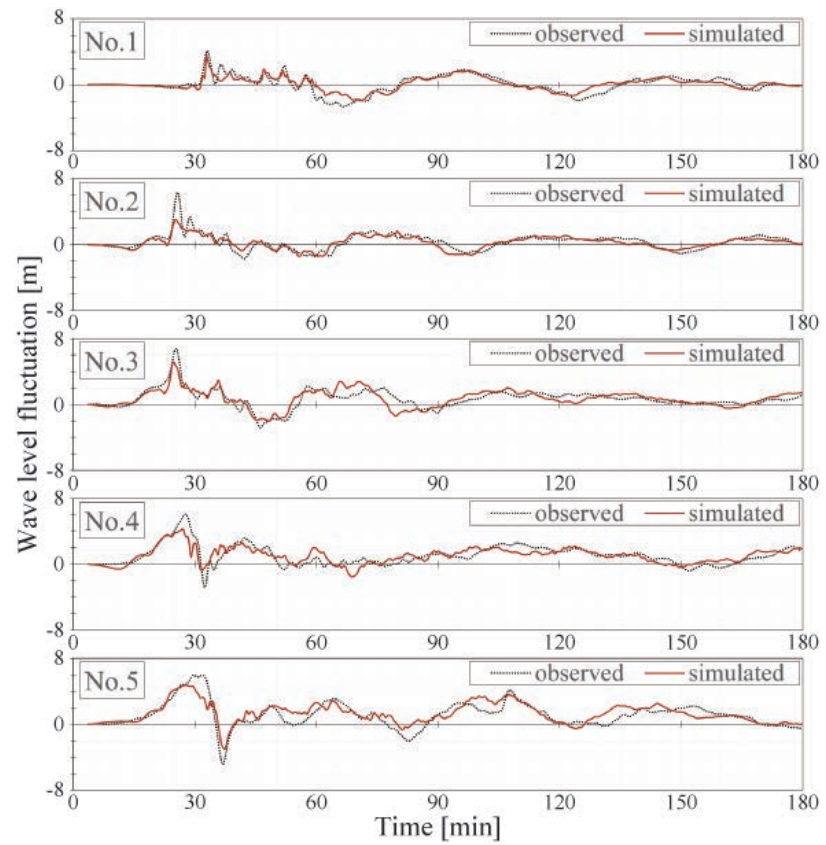

図-10 各観測点における水位変動量の時刻歴

表-4 各解析ケースの計算結果

\begin{tabular}{|c|c|c|c|c|c|}
\hline \multirow{3}{*}{ Case } & \multirow{3}{*}{$\begin{array}{c}\text { すべり量 } \\
\text { (Slip) } \\
{[\times 100(\%)]}\end{array}$} & \multirow{3}{*}{$\begin{array}{c}\text { すべり角 } \\
\text { (Rake) } \\
{[\times 100(\%)]}\end{array}$} & \multicolumn{3}{|c|}{ 最大津波高さ } \\
\hline & & & 仙台 & 石巻 & 釜石 \\
\hline & & & {$[\mathrm{m}]$} & {$[\mathrm{m}]$} & {$[\mathrm{m}]$} \\
\hline A1B1 & 0.700 & 0.877 & 7.911 & 4.626 & 9.845 \\
\hline A1B2 & 0.700 & 0.938 & 7.808 & 4.780 & 9.693 \\
\hline A1B3 & 0.700 & 1.000 & 7.759 & 4.897 & 9.484 \\
\hline A1B4 & 0.700 & 1.062 & 7.590 & 4.982 & 9.210 \\
\hline A1B5 & 0.700 & 1.123 & 7.496 & 5.033 & 8.951 \\
\hline A2B 1 & 0.850 & 0.877 & 9.255 & 5.516 & 11.571 \\
\hline A2B2 & 0.850 & 0.938 & 9.273 & 5.694 & 11.345 \\
\hline A2B3 & 0.850 & 1.000 & 9.272 & 5.834 & 11.077 \\
\hline A2B 4 & 0.850 & 1.062 & 8.986 & 5.927 & 10.757 \\
\hline A2B5 & 0.850 & 1.123 & 8.702 & 5.982 & 10.365 \\
\hline A3B1 & 1.000 & 0.877 & 10.658 & 6.384 & 13.210 \\
\hline A3B2 & 1.000 & 0.938 & 10.612 & 6.598 & 12.956 \\
\hline A3B3 & 1.000 & 1.000 & 10.654 & 6.762 & 12.681 \\
\hline A3B4 & 1.000 & 1.062 & 10.281 & 6.878 & 12.308 \\
\hline A3B5 & 1.000 & 1.123 & 10.205 & 6.943 & 11.828 \\
\hline A4B1 & 1.200 & 0.877 & 12.732 & 7.487 & 15.468 \\
\hline A4B2 & 1.200 & 0.938 & 12.662 & 7.744 & 15.161 \\
\hline A4B3 & 1.200 & 1.000 & 12.603 & 7.942 & 14.836 \\
\hline A4B4 & 1.200 & 1.062 & 12.331 & 8.085 & 14.396 \\
\hline A4B5 & 1.200 & 1.123 & 11.926 & 8.171 & 13.826 \\
\hline A5B 1 & 1.400 & 0.877 & 14.581 & 8.552 & 17.827 \\
\hline A5B2 & 1.400 & 0.938 & 14.582 & 8.823 & 17.516 \\
\hline A5B3 & 1.400 & 1.000 & 14.434 & 9.057 & 17.109 \\
\hline A5B4 & 1.400 & 1.062 & 14.287 & 9.226 & 16.520 \\
\hline A5B5 & 1.400 & 1.123 & 13.875 & 9.338 & 15.906 \\
\hline
\end{tabular}

に続くモンテカルロシミュレーションによる信頼性評 価の入力情報となる. 本研究では, すべり角とすべり 量の 2 つの物理量を基本変数として設定しているため, これらのばらつきを定量化する，具体的には，すべり角 とすべり量の確率密度関数を推定する作業であり, 平 均值, 標準偏差, 分布関数の情報を整理することにな る。この情報整備には，実測データに基づく推定と工 学的知見や経験に基づく推定の 2 種類のアプローチが

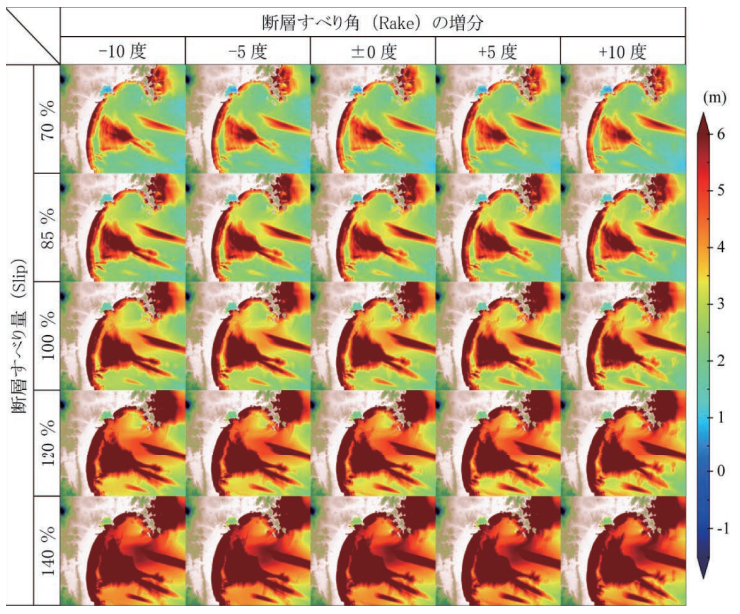

図-11 宮城県沖における最大津波高さの分布

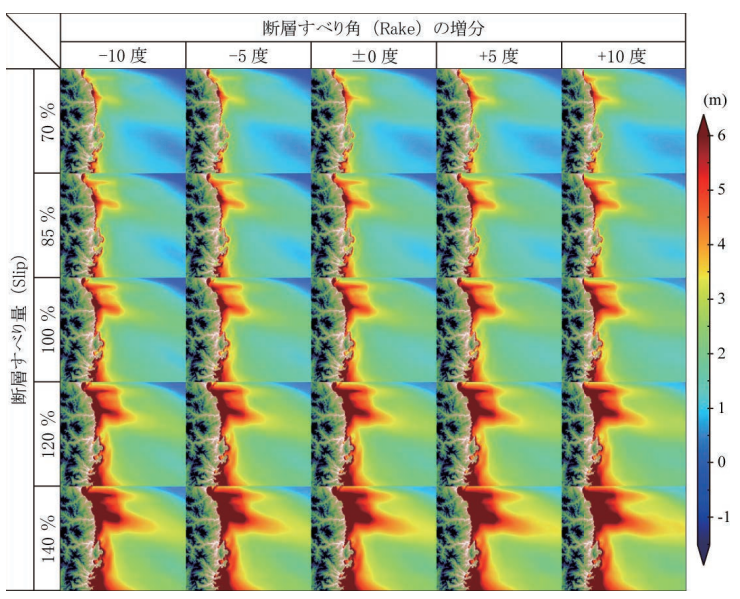

図-12 岩手県沖における最大津波高さの分布

存在する. 実測データが十分にデータベース化されて いる場合は，その情報から推定すればよいが，十分な 情報が揃っていない場合は, 経験的な知見や工学的判 断に頼ることになる. 本研究では, 断層パラメータで あるすべり量とすべり角について，その平均值，標準 偏差，分布関数を設定する必要がある.

まず，ばらつきの与え方と平均值について説明する. 津波解析の解析条件の部分で示したとおり, 本研究で 用いた断層モデルの Fujii-Satake モデル Ver.8.0 は，55 の小断層を含んでおり, 各小断層はすべり角とすべり 量の值を持つ. すべり角は全ての小断層に対して共通 となっているが，す心゙り量は異なる值を持っている，そ こで, シミュレーションの際にパラメータを変動させ た考え方と同様に, Fujii-Satake モデルのパラメータ值 を平均值として，その周辺にばらつきが存在すると考 える. そのため, 基本変数であるす心゙り角とす心゙り量 の平均值は Fujii-Satake モデルのパラメータ值そのもの となり, 先述の応答曲面の説明の中で示したとおり, 基 本変数を Fujii-Satake モデルのパラメータ值で正規化し 
た值を用いるため，平均值は 1.0 となる，また，ばらつ きは平均值に対する割合として表現される。つまり，す べり角とす心゙り量に関して，55 の小断層の中で一律に 変化すると仮定している．また，これら 2 つの基本変 数の分布関数の形状については, 実現象において特別 考慮しなければならないばらつきの偏りは無いと仮定 して，正規分布で評価することとした。

最後に標準偏差の設定根拠について説明する．す心゙ り量の標準偏差は, 平均值に対して $10 \%$ の標準偏差を 意味する 0.1 とした. 正規分布で考えた場合, 分布は標 準偏差の 3 倍程度の広がりを持つため平均值に対して 30\%程度のばらつきを考えていることになる．この設定 根拠は, Kanamori ${ }^{28)}$ のモーメントマグニチュード $M_{w}$ に対してばらつきを与えたことに基づいている， $M_{w}$ は, 断層パラメータの諸量の関数として定義される地 震モーメント $M_{0}$ と以下の式で関係付けられる.

$$
\log M_{0}=1.5 M_{w}+9.1
$$

ここで，

$$
M_{0}=\mu D S
$$

であり, $D$ は断層のすべり量, $S$ は断層面積, $\mu$ は震 源断層付近の媒質の剛性率である. モーメントマグニ チュードのばらつきについては, 断層面積の同じ既往地 震を考慮すると \pm 0.1 程度であることが, 原子力土木委 員会津波評価部会によって示唆されている ${ }^{5)}$. 式(4) と 式(5)において， $\mu$ と $S$ は決定されているとして， $M_{w}$ が 0.1 増加したとすると $D$ が $10^{0.15}=1.41$ 倍となる ことから, すべり量の変動幅は 70〜 140\%程度となるこ とがわかる. 従ってこの変動幅を表現するために, 寸 べり量の標準偏差を 0.1 とした. すべり角についても, 同委員会が，断層の走向を \pm 10 度変化させた確率論的 評価の試算を行っており, 結果的にすべり角が \pm 10 度 程度変化しているため, 本研究でもこの程度のばらつ きを考慮する. 標準偏差の 3 倍程度の広がりを持つと 考え, す心゙り角の標準偏差を 0.04 に設定した。この場 合, すべり角の変動量は 90〜110\%程度（ \pm 10 度程度） となる. 以上で説明した内容を整理したものが表-5で ある。

表-5 入力パラメータの分布情報

\begin{tabular}{c|ccc}
\hline 不確実パラメータ & 平均 & 標準偏差 & 分布形状 \\
\hline すべり量 & 1.0 & 0.1 & 正規分布 \\
すべり角 & 1.0 & 0.04 & 正規分布 \\
\hline
\end{tabular}

\section{5. 信頼性解析}

\section{(1) 応答関数の構築}

これまでに, 仙台・石巻・釜石の 3 地点に関する津 波解析の結果を示した。 以降では, これらの結果に基 づいて, 最大津波高さの応答曲面を構築する. 本研究 では, 断層のすべり量とすべり角の 2 種類の基本変数 を設定しているため，これらを含む応答曲面を考える. なお, 地形などの影響によって, 各地点ですべり量と すべり角が最大津波高さに与える影響の度合いは異な ると考えられる. そのため, 各地点にそれぞれ応答曲 面を構築するものとした. 先述のように, 表-4 は, 津 波解析で得られた各地点のすべり量, すべり角, 最大 津波高さの関係の一覧を示したものである。このデー 夕に基づいて各地点の応答曲面を構築する. まず, 応 答曲面の基本形として，下記のものを採用した。

$$
H_{\max }=\mathrm{a} U+\mathrm{b} \lambda+\mathrm{c} U \lambda+\mathrm{d}
$$

ここで, $H_{\max }$ は最大津波高さ, $U$ はすべり量, $\lambda$ はす べり角であり， a , b , c， d は未定係数である. 未定係 数は, 表-4の結果に整合するように決定される, 応答 曲面の基本形については, 基本変数のべき乗項などの 存在も考えられる. しかしながら，そのような非線形 性の強い項を含む応答曲面の場合, 非物理的な挙動を 示寸可能性が高くなる. 特に, 津波解析で確認した基 本変数の範囲外の領域で予想外の挙動を示す危険性が ある.もちろん, 物理的に非線形項を考慮す心゙き理由 があれば基本形に含めるべきではあるが，表-4 の結果 を見る限り, 応答值（最大津波高さ）は基本変数の変化 に対して概ね線形的であることから，上式の形式で十 分と考えた. また, すべり量とすべり角の積 $U \lambda$ の項 (以降, クロス項と呼ぶ）を, 念のため基本形に含めた.

ここからは, 本研究の中で得られた実際の応答曲面 を示しながら説明を進める. 先述の応答曲面の基本形 には, すべり量の項, すべり角の項, クロス項, 切片の 4 つの項が存在する. このうち切片を除いた 3 つの項の 組み合わせにより，6種類の応答関数が考えられる. 通 常, 多数の変数が存在する条件で最適な応答曲面を求 めるためには, 変数増加法, 変数減少法, ステップワ イズ法などの手法を用いて, 効率的に最適解を求める が, 本研究では, 変数が少ないため, 6 種類すべてにつ いて重回帰分析を行った。表-6 8 8, 各地点（仙台, 石巻, 釜石) の計算結果から得られた応答曲面の係数 と $t$ 值，および各応答曲面の AIC (Akaike's Information Criterion） ${ }^{29)}$ の值を示しており，AIC が最小值をとる 応答曲面を最適なものとして選択した. その結果, 全 ての地点で同じ関数形（表中の AIC の值にアンダーラ 
表-6 重回帰分析より得られた応答曲面（仙台）

\begin{tabular}{|c|c|c|c|c|c|c|c|c|c|}
\hline \multirow{2}{*}{\multicolumn{3}{|c|}{ 関数形 }} & \multicolumn{4}{|c|}{ 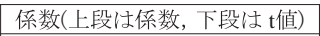 } & \multirow{2}{*}{$R^{2}$} & \multirow{2}{*}{$\begin{array}{l}\text { r.s.e. } \\
{[\mathrm{m}]}\end{array}$} & \multirow{2}{*}{ AIC } \\
\hline & & & A & $\mathrm{b}$ & $\mathrm{c}$ & $\mathrm{d}$ & & & \\
\hline \multicolumn{3}{|c|}{$H_{\max }=\mathrm{a} U+\mathrm{b} \lambda+\mathrm{c} U \lambda+\mathrm{d}$} & $\begin{array}{l}11.238 \\
11.014\end{array}$ & $\begin{array}{l}-0.596 \\
-0.554\end{array}$ & $\begin{array}{l}-1.726 \\
-1.698\end{array}$ & $\begin{array}{l}1.618 \\
1.497\end{array}$ & 0.998 & 0.110 & -33.7 \\
\hline \multicolumn{2}{|c|}{$H_{\max }=\mathrm{a} U+\mathrm{b} \lambda$} & $+\mathrm{d}$ & $\begin{array}{c}9.512 \\
102.877\end{array}$ & $\begin{array}{r}-2.374 \\
-9.032\end{array}$ & & $\begin{array}{c}3.396 \\
12.108 \\
\end{array}$ & 1998 & 0.115 & -32.5 \\
\hline$H_{\max }=\mathrm{a} U$ & & $+\mathrm{d}$ & $\begin{array}{r}9.516 \\
48.476\end{array}$ & & & $\begin{array}{l}1.022 \\
4.917\end{array}$ & .990 & 0.244 & 4.2 \\
\hline$H_{\text {max }}=$ & $\mathrm{b} \lambda$ & $+\mathrm{d}$ & & $\begin{array}{l}-2.374 \\
-0.421\end{array}$ & & $\begin{array}{c}13.193 \\
2.329\end{array}$ & -0.036 & 2.464 & 119.9 \\
\hline$H_{\max }=\mathrm{a} U$ & \multicolumn{2}{|c|}{$+\mathrm{c} U \lambda+\mathrm{d}$} & $\begin{array}{l}11.785 \\
47.126\end{array}$ & & $\begin{array}{r}-2.273 \\
-9.701\end{array}$ & $\begin{array}{c}1.022 \\
11.048\end{array}$ & 0.998 & 0.108 & -35.5 \\
\hline max $=$ & $\mathrm{b} \lambda+$ & $+\mathrm{d}$ & & $\begin{array}{l}-12.084 \\
-17.71\end{array}$ & $\begin{array}{l}9.427 \\
41.93\end{array}$ & $\begin{array}{c}13.193 \\
20.48\end{array}$ & 0.987 & 0.280 & 121.9 \\
\hline
\end{tabular}

表-7 重回帰分析より得られた応答曲面（石巻）

\begin{tabular}{|c|c|c|c|c|c|c|c|c|c|}
\hline \multirow{2}{*}{\multicolumn{3}{|c|}{ 関数形 }} & \multicolumn{4}{|c|}{ 係数(上段は係数, 下段は $\mathrm{t}$ 值) } & \multirow{2}{*}{$R^{2}$} & \multirow{2}{*}{$\begin{array}{r}\text { r.s.e. } \\
{[\mathrm{m}]}\end{array}$} & \multirow{2}{*}{ AIC } \\
\hline & & & $\mathrm{a}$ & $\mathrm{b}$ & $\mathrm{c}$ & d & & & \\
\hline \multirow{2}{*}{\multicolumn{3}{|c|}{$H_{\max }=\mathrm{a} U+\mathrm{b} \lambda+\mathrm{c} U \lambda+\mathrm{d}$}} & 3.630 & 0.0005 & 2.285 & 0.759 & \multirow{2}{*}{0.999} & \multirow{2}{*}{0.057} & \multirow{2}{*}{-67.0} \\
\hline & & & 6.918 & 0.000 & 4.371 & 1.365 & & & \\
\hline \multicolumn{2}{|c|}{$H_{\max }=\mathrm{a} U+\mathrm{b} \lambda$} & $+d$ & 5.914 & 2.353 & & -1.595 & 0.998 & 0.076 & \multirow{2}{*}{-52.8} \\
\hline \multirow[b]{2}{*}{$H_{\max }=\mathrm{a} U$} & & & $\frac{96.000}{5.914}$ & 4.440 & & & & \multirow[b]{2}{*}{0.227} & \\
\hline & & & $\begin{array}{c}5.914 \\
32.354\end{array}$ & & & $\begin{array}{l}0.159 \\
3.917\end{array}$ & 0.978 & & 0.7 \\
\hline \multirow{2}{*}{$H_{\max }=$} & \multirow{2}{*}{$\mathrm{b} \lambda$} & \multirow{2}{*}{$+\mathrm{d}$} & & 2.353 & & 4.497 & \multirow{2}{*}{-0.023} & \multirow{2}{*}{1.532} & \multirow{2}{*}{96.2} \\
\hline & & & & 0.670 & & 6 & & & \\
\hline$H_{\max }=\mathrm{a} U$ & \multicolumn{2}{|c|}{$+\mathrm{c} U \lambda+\mathrm{d}$} & $\begin{array}{c}3.630 \\
28.430\end{array}$ & & $\begin{array}{c}2.285 \\
19.100\end{array}$ & $\begin{array}{c}0.759 \\
16.060\end{array}$ & 0.999 & 0.055 & $\underline{-69.0}$ \\
\hline$H_{\max }=$ & \multicolumn{2}{|c|}{$\mathrm{b} \lambda+\mathrm{c} U \lambda+\mathrm{d}$} & & $\begin{array}{c}-3.710 \\
-15.210\end{array}$ & $\begin{array}{c}5.887 \\
73.200\end{array}$ & $\begin{array}{c}4.497 \\
19.520\end{array}$ & 0.996 & 0.100 & -39.2 \\
\hline
\end{tabular}

表-8 重回帰分析より得られた応答曲面（釜石）

\begin{tabular}{|c|c|c|c|c|c|c|c|c|c|}
\hline \multirow{2}{*}{\multicolumn{3}{|c|}{ 関数形 }} & \multicolumn{4}{|c|}{ 係数(上段は係数, 下段は t值) } & \multirow{2}{*}{$R^{2}$} & \multirow{2}{*}{$\begin{array}{l}\text { r.s.e. } \\
{[\mathrm{m}]}\end{array}$} & \multirow[b]{2}{*}{ AIC } \\
\hline & & & $\mathrm{a}$ & $\mathrm{b}$ & $\mathrm{c}$ & $\mathrm{d}$ & & & \\
\hline \multirow{2}{*}{\multicolumn{3}{|c|}{$H_{\max }=\mathrm{a} U+\mathrm{b} \lambda+\mathrm{c} U \lambda+\mathrm{d}$}} & 16.470 & 0.204 & -5.723 & 1.680 & \multirow{2}{*}{0.999} & \multirow{2}{*}{0.084} & \multirow{2}{*}{-47.0} \\
\hline & & & 21.195 & 0.249 & -7.393 & 2.041 & & & \\
\hline \multicolumn{2}{|c|}{$H_{\max }=\mathrm{a} U+\mathrm{b} \lambda$} & $+\mathrm{d}$ & 10.747 & -5.690 & & 7.575 & 0.997 & 0.156 & -17.3 \\
\hline \multirow[b]{2}{*}{$H_{\max }=\mathrm{a} U$} & & & 10.747 & & & 1.885 & \multirow[b]{2}{*}{0.962} & \multirow[b]{2}{*}{0.540} & \multirow[b]{2}{*}{44.0} \\
\hline & & $+\mathrm{d}$ & 24.710 & & & 4.090 & & & \\
\hline \multirow{2}{*}{$H_{\max }=$} & \multirow{2}{*}{$\mathrm{b} \lambda$} & \multirow{2}{*}{$+\mathrm{d}$} & & -5.690 & & 18.640 & \multirow{2}{*}{-0.009} & \multirow{2}{*}{2.785} & \multirow{2}{*}{126.1} \\
\hline & & & & -0.892 & & 2.911 & & & \\
\hline \multirow{2}{*}{$H_{\max }=\mathrm{a} U$} & \multirow{2}{*}{\multicolumn{2}{|c|}{$-c U \lambda+d$}} & 16.282 & & -5.535 & 1.885 & \multirow{2}{*}{0.999} & \multirow{2}{*}{0.082} & \multirow{2}{*}{$\underline{-49.3}$} \\
\hline & & & 85.990 & & -31.200 & 26.900 & & & \\
\hline \multirow{2}{*}{$H_{\max }=$} & \multirow{2}{*}{\multicolumn{2}{|c|}{$\mathrm{b} \lambda+\mathrm{c} U \lambda+\mathrm{d}$}} & & -16.631 & 10.622 & 18.644 & \multirow{2}{*}{0.981} & \multirow{2}{*}{0.388} & \multirow{2}{*}{-28.4} \\
\hline & & & & 17.610 & & & & & \\
\hline
\end{tabular}

インがついているもの）が最適な応答曲面として選択 された．各地点でそれぞれ別々の関数形が選択される 場合, 基本変数の選択に問題がある可能性があるため, 応答曲面が物理的意味を持つかどうかを考える上では, この結果は良好であると考えられる，なお，表中に示 寸通り，選択された応答曲面における各解析ケースの 計算值と応答曲面との残差標準偏差 (r.s.e.) が最大津波 高さに対して数 \% 程度であり, 回帰式のあてはまりの 良さを表す自由度調整済み決定係数 $R^{2}$ も高いことか ら, 津波解析結果から応答曲面を構築する際の誤差は 考慮しないものとした. 図-13〜15 は, 各地点の最適な 応答曲面を, すべり量, すべり角, 最大津波高さの 3 軸 空間で表現したものである. 青い面が構築した応答曲 面を表し, 赤い点は解析 25 ケースの津波解析による計 算值を表す，なお，すべり量とすべり角の軸範囲には， 表-5における分布に対応していることを明確にするた

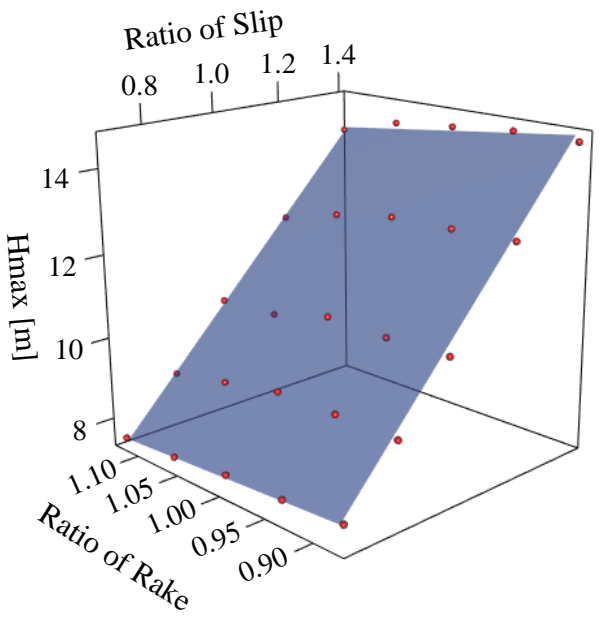

図-13 構築した仙台の応答曲面

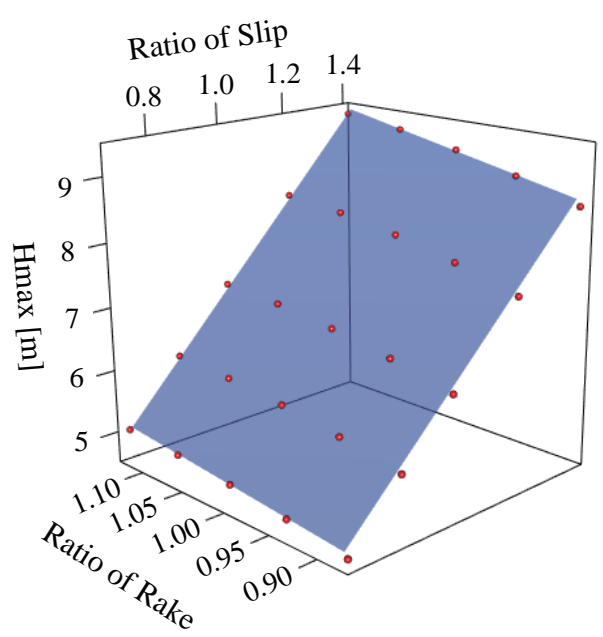

図-14 構築した石巻の応答曲面

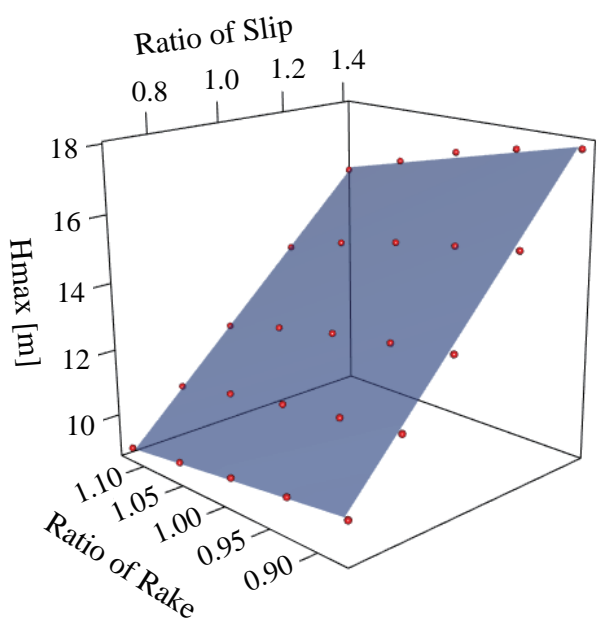

図-15 構築した釜石の応答曲面

めに，Fujii-Satake モデルの基準值で正規化した值を用 いている，表-6〜8および図-13〜15を見ると，3点全 てにおいて，す心゙り量が増大寸るに従い最大津波高さ が増大する傾向がある.すべり量が海底地殼の鉛直変 位に大きく関係する量であるため自明な結果を確認で きたといえる，一方で，す心゙り角に関しては石巻の応 


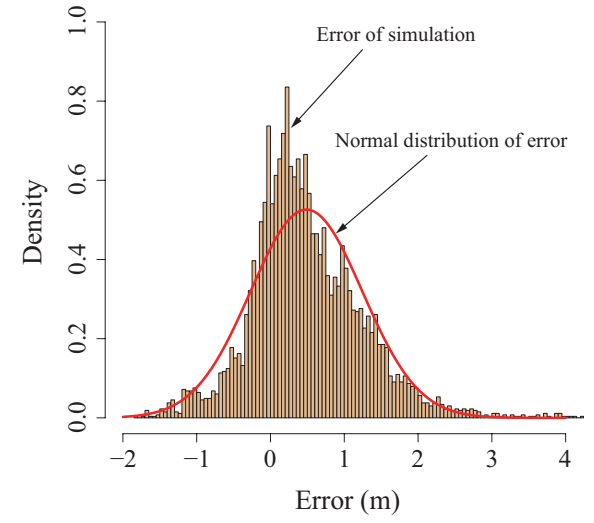

図-16 モデル化誤差のヒストグラムとその正規分布

表-9 基準とした津波痕の観測データ

\begin{tabular}{|c|c|c|c|}
\hline & \multicolumn{2}{|c|}{ 津波痕の座標位置 } & \multirow{2}{*}{$\begin{array}{c}\text { 津波痕 } \\
\text { の高さ } \\
{[\mathrm{m}]} \\
\end{array}$} \\
\hline & $\begin{array}{l}\text { 緯度 } \\
\text { [decim }\end{array}$ & $\begin{array}{c}\text { 経度 } \\
\text { ystem] }\end{array}$ & \\
\hline \multirow{3}{*}{ 仙台 } & 140.986 & 38.2183 & 12.129 \\
\hline & 140.986 & 38.2187 & 11.203 \\
\hline & 140.985 & 38.2184 & 9.317 \\
\hline 石巻 & 141.287 & 38.4139 & 6.902 \\
\hline 釜石 & 141.892 & 39.2650 & 11.4262 \\
\hline
\end{tabular}

答曲面は，仙台と釜石に比べて特異な性質を持つこと がわかる，すべり角が増大寸ると最大津波高さが減少 する仙台と釜石に対して，石巻では最大津波高さが増 加している.この違いは, 応答曲面の中では, クロス 項の係数の符号の違いとして現れる。この理由につい て考えると, 最大津波高さの取得地点が地震波源から 遠く, 陸に近い点であるため, 断層のすべり量やす心゙ り角の変化だけが，石巻の最大津波高さに影響してい るわけではないといったことが考えられる，従って，海 底地形の変化による波の浅水変形, 反射や屈折, さら には断層モデルと石巻との位置関係が半島を挟む地形 となっているために起こる回折など，非線形効果の影 響が応答曲面に含まれていることが考えられる。この ような地形特性を傾向として得られることは，津波八 ザード評価の議論を進めていく上で貴重な情報となる．

\section{(2) モデル化誤差の表現}

本研究では, 実現象に対する数值解析の誤差を定量 化し，その影響を応答曲面に含めて表現することで，数 值解析手法のモデル化誤差についても考慮するものと した，すなわち，応答曲面を次のように再定義する.

$$
H_{\max }=\mathrm{a} U+\mathrm{b} \lambda+\mathrm{c} U \lambda+\mathrm{d}+\mathrm{M}_{\text {err }}
$$

ここに，

$$
\mathrm{M}_{\mathrm{err}}=H_{\mathrm{obs}}-H_{\mathrm{sim}}
$$

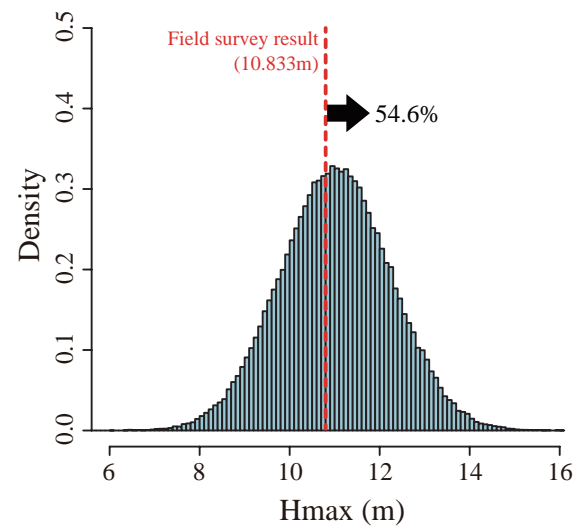

図-17 仙台の確率密度分布と超過確率

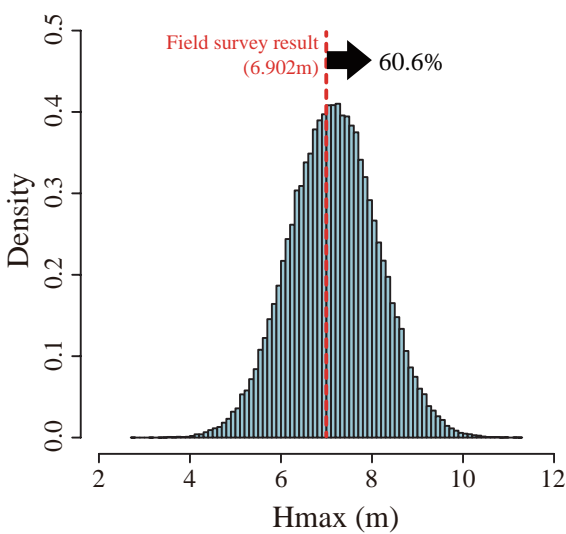

図-18 石巻の確率密度分布と超過確率

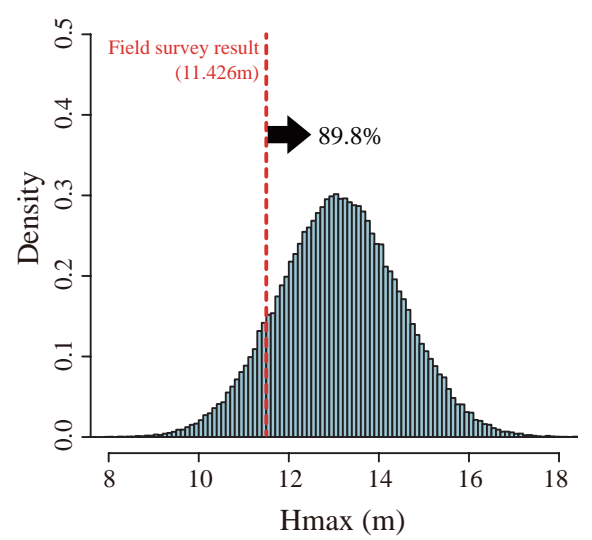

図-19 釜石の確率密度分布と超過確率

である。ここで， $\mathrm{M}_{\mathrm{err}}$ はモデル化誤差である．また右 辺は，図-10に示寸水位変動量の各時刻における実測值 と計算值の差を表す，本研究では，ある程度妥当性が 検討できている点での誤差をモデル化誤差として定量 化するため, 観測 5 地点全ての $\mathrm{M}_{\mathrm{err}}$ を合わせて考慮し た分布を算出した。本来であれば，モデル化誤差を各 地点の最大津波高さを用いた正規化によって無次元化 し，任意の評価地点に適用することが望ましい，しか しながら，本研究では，用いる観測地点が 5 地点のみ であるため，モデル化誤差の分布の評価が難しい，そ こで，本研究では，上述のように図-10の時系列データ 
全体の実測值と解析值の平均的な差をモデル化誤差と して評価した，本研究におけるモデル化誤差の扱いに ついては，不完全なものであることを前提として，全 く考慮しないよりは良いという判断により用いている. 図-16が得られた分布であり，モデル化誤差は正規分布 で表現できると考えられ，この場合の平均值は $0.49[\mathrm{~m}]$, 標準偏差は $0.76[\mathrm{~m}]$ となった。 なお，図-16には，得ら れた平均值と標準偏差で表現した正規分布を重祆て示 している.

\section{(3) モンテカルロシミュレーション}

ここまでに説明した応答曲面と定量化した基本変数 のばらつきの情報を用いて，モンテカルロシミュレー ションを行う．具体的には，定量化したすべり角とす心゙ り量のばらつきの情報に基づいて乱数を発生させ，そ こから任意の基本変数の組み合わせ生成し，それを応 答曲面の関数に代入することで，最大津波高さを計算 する作業を繰り返す。これにより，最大津波高さの確率 密度分布が得られる，本研究では，試行回数を 1 万回 として確率密度分布を求めた。

\section{（4）超過確率の算出}

前節で確率密度分布に対して, 基準值となる最大津 波高さを設定することで，その基準值に対する超過確 率が算出できる，本研究では算出した超過確率の妥当 性を概ね検討し得るものとして，東北地方太平洋沖地 震の津波の痕跡高を基準值とし，超過確率を算出した. 基準値には，表-9 に示寸東北地方太平洋沖地震津波合 同調査グループが提供寸る現地踏査による津波の痕跡 高の観測值 ${ }^{30}$ を用いた。なお仙台については隣接する 痕跡高のデータにばらつきがあったため，3 地点の平均 值 $10.883[\mathrm{~m}]$ を採用した。超過確率を算出した結果を 図-17 19に示す．結果として，仙台及び石巻において はその中央值が概ね津波痕の観測值と一致し，仙台の 超過確率が $54.6 \%$ ，石巻の超過確率が $60.6 \%$ となった。 今回の断層モデルは東北地方太平洋沖地震時のものを 想定しているため，超過確率としては概数妥当な結果 であると考えられる。一方，釜石に関しては超過確率 が $89.8 \%$ となり，想定する最大津波高さが実際のもの よりも大きいものとなった。この理由として，解析条 件に陸側境界に完全反射境界を用いたため，入り組ん だ湾形状の釜石では湾内で波が増幅し，実際のものよ りも過大に評価されたためと考えられる。

\section{6. おわりに}

本研究では, 昨今要求される大きな津波外力の適切 な評価を達成するため, 現象の確率場を数值解析の情
報から定量的に表現できる枠組みの構築を目的とした. そこで，地盤工学分野で確立されている信頼性解析の 枠組みを基礎として, 津波ハザード評価に対して数值 解析の情報を直接的に関係付けるアプローチを試みた. その結果，得られた成果を以下にまとめる.

- 近年の高度な数值解析技術によって得られる詳細 な工学的情報を確率場に対してより密に与え，か つそれを低計算コストで達成するための評価手法 を提案した。

- 提案する枠組みに基づいて実際に津波ハザード評 価を行った結果，構築した応答曲面に地形の影響 が考慮された。従って不確実性と地域特性との関 係性が得られ，本枠組みを通して数值解析結果を 津波ハザード評価に適用することで，詳細かつ議 論する上で貴重な工学的情報を提供することを確 認した.

本研究では, 不確実性として, 現象を強く支配する すべり量とすべり角に着目して検証を行ったが，本来 は定量化できる全ての不確実性を考慮するのが望まし い。この枠組みは，そのような考慮すべき膨大な不確 実性を，多变量解析により効率的に検討できるのも利 点となる．また，提案する枠組みの実施例を通して，解 析条件や解析パラメータを定量的に評価しながら津波 解析を重衫ることで，実施者自身が体系的に工学的知 識や判断力を養うことができる点も特徴である.

今後，より多くの不確実性を考慮して信頼的な検証 を重衫ると共に，実務利用を想定した結果の取り扱い 方法を詳細に検討していくことが課題となる.

\section{参考文献}

1) Cornell, C. A.: Engineering seismic risk analysis, Bulletin of Seismological Society of America, Vol.58, No.5, pp.15831606, 1968.

2）象田弘行: 地震動の設定と発生確率, 特集一原子力発電所の 地震時危険度の確率論的評価, 日本原子力学会誌, Vol.28, No.1, pp.6-11, 1986.

3）原子力土木委員会津波評価部会 : 原子力発電所の津波評 価技術, 土木学会, 2002. (http://committees.jsce.or.jp/ceof $\mathrm{np} / \mathrm{node} / 5,2015$ 年 10 月 5 日アクセス)

4）原子力土木委員会津波評価部会: 津波評価手法の高精度化 研究, 土木学会論文集 B, Vol.63, No.2, pp.168-177, 2007.

5) 原子力土木委員会津波評価部会 : 確率論的津波八ザー ド解析の方法, 土木学会, 2011. (http://committees.jsce.or.j $\mathrm{p} /$ ceofnp/node/39, 2015 年 10 月 5 日アクセス)

6) 原子力安全基盤機構 : 確率論的手法に基づく基準津波策 定手引き, JNES-RE-Report-Series, 2013-2041, 2014.

7) 相田勇: 三陸沖の古い津波のシミュレーション, 東京大学 地震研究彙報, Vol.52, pp.71-101, 1977.

8）越村俊一, 香月恒介, 茂渡悠介：GPU コンピューティン グによる津波解析の高速化とリアルタイム浸水予測, 土 木学会論文集 B2（海岸工学），Vol.66, No.1, pp.191-195, 2010. 
9) Cornell, C. A.: First-order uncertainty analysis of soil deformation and stability, Proc. 1st Int. Conf., Application of Statistic and Probability in Soil and Structural Engineering, Hong Kong, pp.130-143, 1971.

10) Cambou, B.: Application of first-order uncertainty analysis in the finite element method in linear elasticity, Proc. 3rd ICASP, Aachen, pp.67-87, 1975.

11) 中桐滋, 久田俊明, 系谷康宏 : 確率有限要素法による形状 に不確かさを有する構造の解析, 日本機械学会論文集 (A 編）, Vol.48, No.427, pp.339-348, 1982.

12）桜井春輔, 土居康成 : 有限要素法による斜面の信頼性解 析, 土木学会論文集, No.330, pp.87-97, 1983.

13）鈴木誠, 石井清 : 確率有限要素法による斜面安定解析, 土 木学会論文集, No.364/III-4, pp.199-208, 1985.

14) Zhang, J., Zhang, L. M. and Tang, W. H.: Kriging numerical models for geotechnical reliability analysis, Soils and Foundations, Vol.51, No.6, pp.1169-1177, 2011.

15) 本城勇介, 大竹雄, 原隆史 : ETC10 例題のレベル III 信頼 性設計, JCOSSAR 2011 論文集, pp.615-622, 2011.

16) Honjo, Y.: Challenges in geotechnical reliability based design, Proceedings of 3rd International Symposium on Geotechnical Safety and Risk, pp.11-27, 2011.

17) 大竹雄, 本城勇介: 応答曲面を用いた実用的な地盤構造物 の信頼性設計法 : 液状化地盤上水路の耐震設計一の適用, 土木学会論文集 C（地圈工学）, Vol.68, No.1, pp.68-83, 2012.

18）森口周二, 大竹雄, 高瀬慎介, 寺田賢二郎, 小坂祐司, 堀内 克, 沢田和秀, 八嶋厚 : 個別要素法による落石の確率論的 危険度評価, 地盤工学ジャーナル, Vol.10, No.4, 2015.

19) 今村文彦, 首藤伸夫 : 津波高さに及ぼす断層パラメータ推 定誤差の影響, 海岸工学論文集, Vol.36, pp.178-182, 1989.

20) Satake, K., Fujii, Y., Harada, T. and Namegawa, Y.: Time and space distribution of coseismic slip of the 2011 Tohoku earthquake as inferred from tsunami waveform data,
Bulletin of the Seismological Society of America, Vol.103, No.2B, pp.1473-1492, 2013.

21) Okada, Y.: Internal deformation due to shear and tensile faults in a half-space, Bulletin of the Seismological Society of America, Vol.82, No.2, pp.1018-1040, 1992.

22) 後藤智明, 小川由信 : Leap-Flog 法を用いた津波の数值計 算法, 東北大学工学部土木工学科, pp.52, 1982.

23) 内閣府 : 南海トラフの巨大地震モデル検討会（第二 次報告），津波断層モデル編 - 津波断層モデルと津波 高・浸水域等について - , 2012. (http://www.bousai.go.j $\mathrm{p} / \mathrm{jishin} / \mathrm{nankai} / \mathrm{model} /, 2015$ 年 10 月 5 日アクセス)

24) Amante, C. and Eakins, B. W.: ETOPO1 1 Arc-Minute Global Relief Model: Procedures, Data Sources and Analysis, NOAA Technical Memorandum NESDIS NGDC24, National Geophysical Data Center, NOAA, 2009. doi:10.7289/V5C8276M [August 1, 2014].

25）国土地理院: 基盤地図情報ダウンロードサービス, http://w ww.gsi.go.jp/kiban/

26）日本水路協会 : 海図ネットショップ, http://www.jha.or.j p/shop/

27）国土交通省港湾局 HP : 全国港湾海洋波浪情報網（ナウ ファス), http://www.mlit.go.jp/kowan/nowphas/

28) Kanamori, H.: The energy release in great earthquakes, $J$ ournal of Geophysical Research, Vol.82, No.20, 1977.

29) Akaike, H.: Information theory and an extension of the maximum likelihood principle, Proceedings of the 2nd International Symposium on Information Theory, Petrov, B. N. and Caski, F. (eds.), Akadimiai Kiado, Budapest, pp.267-281, 1973.

30) 東北地方太平洋沖地震津波合同調査グループ: The 2011 off the Pacific coast of Tohoku Earthquake Tsunami Information, http://www.coastal.jp/ttjt/index.php

(2015. 12. 8 受付)

\title{
NUMERICAL-ANALYSIS-AIDED PROBABILISTIC TSUNAMI HAZARD EVALUATION USING RESPONSE SURFACE
}

\author{
Takuma KOTANI, Shinsuke TAKASE, Shuji MORIGUCHI, Kenjiro TERADA, \\ Yo FUKUTANI, Yu OTAKE, Kazuya NOJIMA and Masaaki SAKURABA
}

This study presents a new framework of the probabilistic tsunami hazard evaluation which enables us to use numerical simulation effectively. The basic idea of the framework had been proposed for the reliability analysis of geostructures, and the key issue of the framework is use of the response surface which obtained from the results of numerical simulations. In this study, the response surface of the tsunami height is obtained from the results of the tsunami simulation. In addition, uncertainties related to tsunami simulations are quantified. By using the framework, we can create an environment in which the Monte Carlo Simulation can be performed based on highly-developed numerical simulations. The proposed framework is finally applied to the probabilistic evaluation of the tsunami that was induced by the great east Japan earthquake. The probability density distributions of tsunami height at Sendai, Ishinomaki, and Kamaishi were evaluated with consideration of uncertainties of some fault parameters and a modeling error of the numerical simulation. The obtained results indicate that the framework is effective for the probabilistic tsunami hazard evaluation. 